\title{
The Role of Autoantibodies in Arrhythmogenesis
}

\author{
$\operatorname{Jin} \mathrm{Li}^{1,2}$ (1) \\ Accepted: 11 November 2020 / Published online: 25 November 2020 \\ (C) The Author(s) 2020
}

\begin{abstract}
Purpose of Review The role of autoantibodies in arrhythmogenesis has been the subject of research in recent times. This review focuses on the rapidly expanding field of autoantibody-mediated cardiac arrhythmias.

Recent Findings Since the discovery of cardiac autoantibodies more than three decades ago, a great deal of effort has been devoted to understanding their contribution to arrhythmias. Different cardiac receptors and ion channels were identified as targets for autoantibodies, the binding of which either initiates a signaling cascade or serves as a biomarker of underlying remodeling process. Consequently, the wide spectrum of heart rhythm disturbances may emerge, ranging from atrial to ventricular arrhythmias as well as conduction diseases, irrespective of concomitant structural heart disease or manifest autoimmune disorder.

Summary The time has come to acknowledge autoimmune cardiac arrhythmias as a distinct disease entity. Establishing the autoantibody profile of patients will help to develop novel treatment approaches for patients.
\end{abstract}

Keywords Atrial fibrillation $\cdot$ Autoantibodies $\cdot$ Autoimmunity $\cdot$ Cardiac arrhythmias $\cdot$ Cardiac conduction disease $\cdot$ Ventricular arrhythmia

\section{Introduction}

With the conceptualization of the contradictory capacity of the immune system to self-defend and self-destruct at the same time, the term autoimmunity was first coined over a century ago $[1 \bullet, 2]$. Beyond the philosophical implication, this vital paradox shaped our present-day understanding of disease development when self-tolerance is lost and autoantibodies considered a sine qua non of the condition $[1 \cdot 3]$. The contribution of autoimmunity in cardiovascular diseases in general is largely under-recognized, even more in the context of heart rhythm disturbances. While anatomical features and genetic background were classically seen as the substrates for cardiac arrhythmias, in recent years, it has become increasingly clear that functional autoantibodies can induce arrhythmias by

This article is part of the Topical Collection on Invasive Electrophysiology and Pacing

Jin $\mathrm{Li}$

jin.li@ibmm.unibe.ch; jin.li@ chuv.ch

1 Institute of Biochemistry and Molecular Medicine, University of Bern, Bühlstrasse 28, 3012 Bern, Switzerland

2 Department of Cardiology, Lausanne University Hospital, rue du Bugnon 46, 1011 Lausanne, Switzerland interfering with ion channels and receptors, the key determinants of cardiac electrophysiology. This review focuses on autoantibody-mediated cardiac arrhythmias, classifying them in three sections, according to their origin: atrial, nodal, and ventricular (Fig. 1). Table 1 summarizes the current literature on autoantibody-induced ECG abnormalities, the prevalence, and associated clinical features.

\section{Autoantibodies and Atrial Arrhythmias}

The first evidence supporting a possible role of autoantibodies in the development of atrial arrhythmias derived from a smallscale study describing anti-myosin heavy chain autoantibodies in $60 \%$ of patients with atrial fibrillation $(\mathrm{AF})[3,4]$. Because growing evidence supports the significance of the cardiac autonomic nervous system in AF development, conceptually, it makes sense that binding of functional autoantibodies to $\mathrm{G}$ protein-coupled receptors be associated with $\mathrm{AF}$ [35]. As parasympathomimetic and sympathomimetic agonists, respectively, anti- $\mathrm{M}_{2}$-muscarinic acetylcholine and anti- $\beta_{1}$-adrenergic receptor autoantibodies, were naturally presumed to contribute to AF pathogenesis. In fact, several studies demonstrated that anti- $\mathrm{M}_{2}$-muscarinic acetylcholine and anti- $\beta_{1}$-adrenergic receptor autoantibodies are independent 


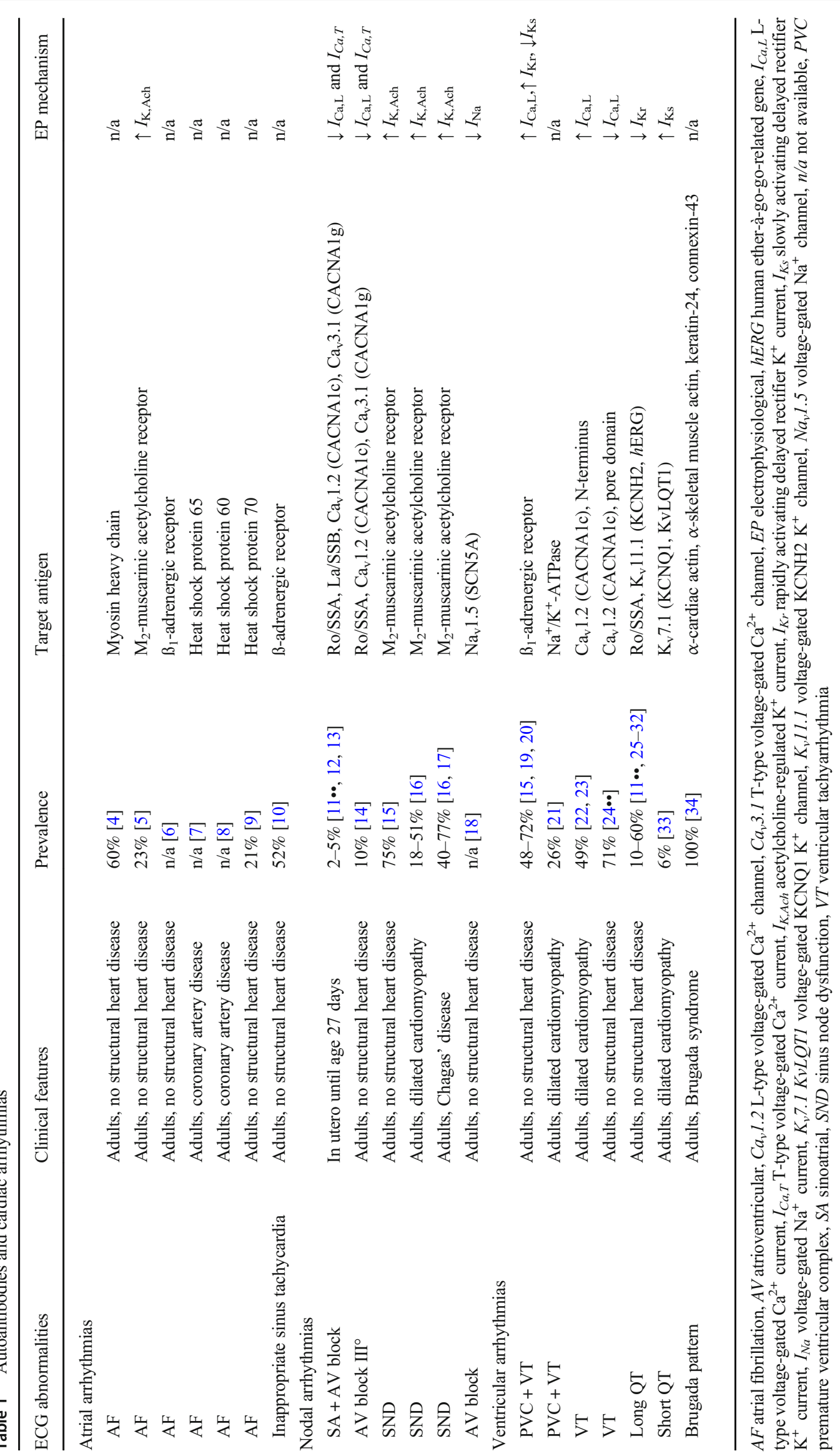




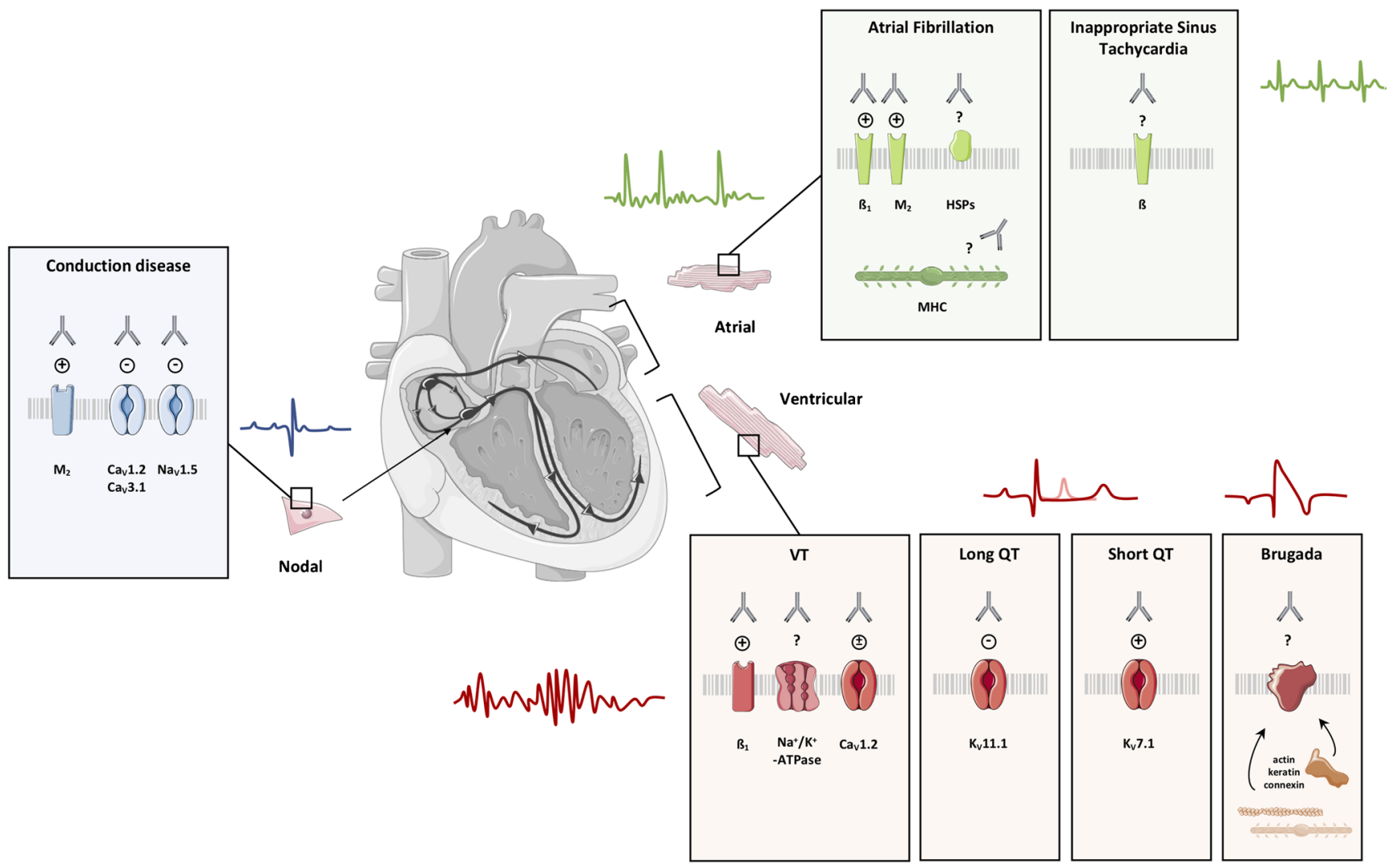

Fig. 1 Summary of autoantibodies related to atrial fibrillation, inappropriate sinus tachycardia, conduction diseases and ventricular arrhythmias, identified so far. $\beta$ B-adrenergic receptor, $\mathrm{Ca}_{\mathrm{v}} 1.2 \mathrm{~L}$-type voltage-gated $\mathrm{Ca}^{2+}$ channel, $\mathrm{Ca}_{\mathrm{v}} 3.1 \mathrm{~T}$-type voltage-gated $\mathrm{Ca}^{2+}$ channel, HSP heat shock protein, $\mathrm{K}_{\mathrm{v}} 7.1$ voltage-gated $\mathrm{KCNQ} 1 \mathrm{~K}^{+}$channel,

predictors of $\mathrm{AF}$ in patients with no underlying structural heart disease $[5,6,36]$. Moreover, studies have shown that anti- $\mathrm{M}_{2-}$ muscarinic acetylcholine and anti- $\beta_{1}$-adrenergic receptor autoantibodies can be used as predictive markers of AF recurrence 1 year after ablation therapy [37, 38]. Animal studies addressing the pathophysiological mechanism have shown the potential of anti- $\mathrm{M}_{2}$-muscarinic acetylcholine and anti- $\beta_{1}$-adrenergic receptor autoantibodies to induce atrial structural (fibrosis) and electrophysiological remodeling (increased anti- $\mathrm{M}_{2}$-muscarinic acetylcholine receptor- $I_{\mathrm{K}, \mathrm{Ach}}$ pathway, atrial effective refractory period shortening), thus forming the underlying substrate for AF (increased atrial arrhythmogenicity) $[5,39-42]$. Nevertheless, the role of anti- $\mathrm{M}_{2}$-muscarinic acetylcholine and anti- $\beta_{1}$-adrenergic receptor autoantibodies as mere bystander, biomarker, or pathogen in $\mathrm{AF}$ is being scrutinized, and the causal relationship remains a matter of ongoing debate [3, 43]. Heat shock proteins (HSPs) are intracellular chaperones that help to preserve cellular integrity through proper protein folding and conformation [43]. In response to stress, HSPs are translocated to the plasma membrane and thus present potential targets for circulating autoantibodies [43]. Accordingly, invasive procedures such as cardiac surgery expose cardiomyocytes to stressful stimuli and
$\mathrm{K}_{\mathrm{v}} 11.1$ voltage-gated $\mathrm{KCNH} 2 \mathrm{~K}^{+}$channel, $\mathrm{M}_{2} \mathrm{M}_{2}$-muscarinic acetylcholine receptor, $\mathrm{Na}_{\mathrm{v}} 1.5$ voltage-gated $\mathrm{Na}^{+}$channel, VT ventricular tachyarrhythmia, \pm stimulation/inhibition. This image was produced using images modified from Servier Medical Art

presumably induce the production of anti-HSP autoantibodies [7, 8]. Anti-HSP65 and anti-HSP60 autoantibodies have been reported in post-operative AF, while anti-HSP70 autoantibodies are associated with $\mathrm{AF}$ recurrence post-ablation therapy [7-9]. At present, the role of anti-HSP autoantibodies in the pathogenesis of $\mathrm{AF}$ remains unclear.

Inappropriate sinus tachycardia is a diagnosis of exclusion and manifests as unexpectedly elevated resting heart rate and/ or disproportionate heart rate response to physical activities, in a structurally normal heart $[3,44]$. The etiology has yet to be elucidated, but one study explored the link between inappropriate sinus tachycardia and anti- $\beta$-adrenergic receptor autoantibodies [10]. Interestingly, anti- $\beta$-adrenergic receptor autoantibodies were identified in half of the patients and accounted for the positive chronotropic effect on rat cardiomyocytes through stimulation of the $\beta$-adrenergic receptor [10].

\section{Autoantibodies and Nodal Arrhythmias}

It was in 1976 when Fairfax and Doniach first described the existence of autoantibodies targeting the cardiac conduction tissue in patients with left bundle branch block [45]. Barely a 
decade later, the involvement of autoantibodies in cardiac conduction disturbances has evolved substantially $[11 \bullet, 46]$. Anti-Ro/SSA and anti-La/SSB immunoglobulins (named after the patients' name they were extracted from/Sjögren's Syndrome autoantigen A and B, respectively) are the archetypal autoantibodies in arrhythmogenesis. Best known in the context of autoimmune connective tissue disorders, the Ro/ SSA and La/SSB antigens are intracellular ribonucleoproteins to which autoantibodies are found in correlation with perinatal cardiac conduction disturbances [11••]. Anti-Ro/SSA and anti-La/SSB positive mothers have a $2-5 \%$ risk of delivering an infant with congenital heart block (CHB), a disease spectrum encompassing conduction abnormalities affecting the sinoatrial (SA) and atrioventricular (AV) nodes of fetuses and neonates $[11 \bullet \cdot, 12,13]$. While resolution of sinus bradycardia and lower-degree AV block is generally observed either spontaneously or after maternal immunosuppressive therapy (steroids, plasmapheresis and/or intravenous immunoglobulin), thirddegree AV block is irreversible $[11 \bullet \bullet, 47-50]$. Anti-Ro/SSA may react with two different subtypes of the Ro antigen, referred to as anti-Ro/SSA-52kD and anti-Ro/SSA-60kD according to the different molecular weights. Anti-Ro/SSA$52 \mathrm{kD}$ has become the main focus of interest with its predominant role in CHB. Numerous studies on animals (ranging from murine to rat, guinea pig, and rabbit models) as well as fetal human hearts have provided evidence that anti-Ro/SSA antibodies from sera of mothers lead to CHB through transplacental passage as early as 11 weeks of gestational age and cross-reaction with the $\mathrm{Ca}^{2+}$ channels (L- and T-type) of the fetal cardiac conduction system $[11 \bullet \bullet]$. The subsequent inhibition of $\mathrm{Ca}^{2+}$ currents $\left(I_{\mathrm{Ca}, \mathrm{L}}\right.$ and $\left.I_{\mathrm{Ca}, \mathrm{T}}\right)$ disrupts the pulse generation and propagation in SA and AV nodes [11••]. Furthermore, the chronic exposure to anti-Ro/SSA downregulates the surface expression of L-type $\mathrm{Ca}^{2+}$ channels resulting in apoptotic cell death and triggering inflammation [11••]. This process ultimately leads to fibrosis and calcification of the conduction system, characteristic of CHB $[11 \bullet$, 51]. Because CHB does not develop systematically in all anti-Ro/SSA-positive pregnancies, the involvement of other autoantibodies has been suggested including autoantibodies targeting calreticulin, the $\mathrm{M}_{1}$-muscarinic acetylcholine receptor, $\alpha$-fodrin, $\alpha$-enolase, serotoninergic 5 hydroxytryptophane $\left(5-\mathrm{HT}_{4}\right)$ receptor, and endogenous retrovirus-3 placental protein [13, 46, 52-58]. However, investigations on these autoantibody candidates are limited to case studies. Their underlying mechanism and clinical relevance remain uncertain [46].

In adults, the association between anti-Ro/SSA autoantibodies and cardiac conduction disturbances is less evident $[11 \bullet, 59]$. Unlike the fetal heart, the expression of L- and Ttype $\mathrm{Ca}^{2+}$ channels is higher in adults, rendering them more resistant to anti-Ro/SSA-induced $\mathrm{Ca}^{2+}$ current inhibition $[11 \bullet \bullet, 59]$. Nevertheless, based on a retrospective study, it is estimated that about $10 \%$ of adults with isolated third-degree AV block is related to anti-Ro/SSA autoantibodies [14]. Another autoantibody associated with cardiac conduction disease targets the $\mathrm{M}_{2}$-muscarinic acetylcholine receptor. It has been detected in $75 \%$ of patients with primary sinus node dysfunction and was more commonly reported in dilated cardiomyopathy and Chagas' disease with sinus node dysfunction [3, 15-17]. Anti- $\mathrm{M}_{2}-\mathrm{AChR}$ autoantibodies presumably act as agonists on the $\mathrm{M}_{2}$-muscarinic acetylcholine receptor, which subsequently inhibits the $\mathrm{Ca}^{2+}$ current $\left(I_{\mathrm{Ca}, \mathrm{L}}\right)$ and activates the acetylcholine-regulated $\mathrm{K}^{+}$current $\left(I_{\mathrm{K}, \mathrm{ACh}}\right)$ of SA nodes. Finally, one study detected for the first time, autoantibodies targeting the cardiac voltage-gated $\mathrm{Na}^{+}$channel $\left(\mathrm{Na}_{V} 1.5, \mathrm{SCN} 5 \mathrm{~A}\right)$ in patients with idiopathic high-degree AV block (second-degree AV block Mobitz type II and third-degree AV block) [18]. Because the autoantibody screening was performed in the pooled serum of 10 patients, the prevalence of anti- $\mathrm{Na}_{\mathrm{v}} 1.5$ autoantibody-mediated $\mathrm{AV}$ block cannot be determined. The serum of these patients with conduction disease reduced the $\mathrm{Na}^{+}$current $\left(I_{\mathrm{Na}}\right)$ density in rat cardiomyocytes compared to the serum of healthy controls [18]. Moreover, rats with anti- $\mathrm{Na}_{\mathrm{v}} 1.5$ autoantibodies consistently developed intermittent third-degree AV block and SA block [18]. The proposed mechanism is a downregulation of $\mathrm{Na}_{\mathrm{v}} 1.5$ channel expression leading to $I_{\mathrm{Na}}$ reduction, an impairment that the AV nodal region is particularly vulnerable to, owing to the localized lower $\mathrm{Na}^{+}$channel density [18].

\section{Autoantibodies and Ventricular Arrhythmias}

Disruption of cardiac repolarization appears to be the common electrophysiological pathway of autoantibodies leading to ventricular arrhythmias.

Autoantibodies targeting $\beta_{1}$-adrenergic receptors were described in a variety of cardiac diseases including dilated cardiomyopathy (26-95\%), ischemic cardiomyopathy (10$55 \%$ ), and Chagas' disease (30-98\%) [60, 61••]. Soon after discovering their sympathomimetic effect, it became clear that their contribution to arrhythmogenesis was not limited to structural remodeling process (e.g., myocardial hypertrophy, ventricular dilatation, and dysfunction). Anti- $\beta_{1}$-adrenergic receptor autoantibodies were reported in $48-72 \%$ of patients with clinical signs of ventricular electrical instabilities, ranging from frequent premature ventricular complexes (PVCs) to sustained ventricular tachyarrhythmias (VTs), despite a structurally normal heart $[15,19,20]$. The suggested mechanism of anti- $\beta_{1}$-adrenergic receptor autoantibody-mediated ventricular arrhythmias is $\beta$-adrenergic stimulation leading to ion channel remodeling including adrenergically enhanced inward $I_{\mathrm{Ca}, \mathrm{L}}$ and increased rapidly activating delayed rectifier $\mathrm{K}^{+}$current $\left(I_{\mathrm{Kr}}\right)$ along with reduced slowly activating delayed $\mathrm{K}^{+}$current 
$\left(I_{\mathrm{Ks}}\right)[62,63]$. The net effect is an abnormally prolonged cardiac repolarization, the substrate for lethal arrhythmias.

During activation of the sympathetic nervous system, $\mathrm{Na}^{+} /$ $\mathrm{K}^{+}$-ATPase is an integral player of the adrenergic response [64]. In this context, one study detected autoantibodies directed against $\mathrm{Na}^{+} / \mathrm{K}^{+}$-ATPase in $26 \%$ of patients with dilated cardiomyopathy [21]. Anti- $\mathrm{Na}^{+} / \mathrm{K}^{+}$-ATPase autoantibodypositive patients presented more frequently PVCs and nonsustained VTs [21]. After 31 months of follow-up, the presence of anti- $\mathrm{Na}^{+} / \mathrm{K}^{+}$-ATPase autoantibodies was an independent predictor of sudden cardiac death [21]. The exact pathomechanism is not known, but an impaired $\mathrm{Ca}^{2+}$ signaling cascade is suspected [21].

Pertaining to $\mathrm{Ca}^{2+}$ handling abnormalities, autoantibodies targeting the N-terminus of the L-type voltage-gated $\mathrm{Ca}^{2+}$ channel $\left(\mathrm{Ca}_{\mathrm{v}} 1.2, \alpha 1 \mathrm{c}\right.$ pore-forming subunit or CACNA1c) are present in $49 \%$ of patients with dilated cardiomyopathy [22]. The autoantibody was an independent predictor of VT and sudden cardiac death after a mean follow-up period of 32 months [22]. Experimental studies demonstrated an autoantibody-mediated prolongation of action potential duration (APD) and induction of early afterdepolarizations (EADs) through enhancement of $I_{\mathrm{Ca}, \mathrm{L}}[22,23]$. In addition, anti-Ca 1.2 autoantibodies induced VT in rat hearts [22]. And yet, how the autoantibody interacts with an intracellular epitope of the $\mathrm{Ca}^{2+}$ channel remains unknown $[22,23]$. Only recently, a novel autoantibody targeting an extracellular domain of the cardiac $\mathrm{Ca}^{2+}$ channel $\left(\alpha 1 \mathrm{c}, \mathrm{Ca}_{\mathrm{v}} 1.2\right)$ was discovered and related to VT underlying sudden cardiac arrest in patients without any structural heart disease [24••]. Functional studies demonstrated the proarrhythmogenic effect of anti-Ca 1.2 autoantibodies in human-induced pluripotent stem cell-derived cardiomyocytes through inhibition of $\mathrm{Ca}_{\mathrm{v}} 1.2$ channels and subsequent APD shortening [24••]. Given the close proximity of the target site to the pore of the channel, it is speculated that alteration of the ion selectivity and permeability filter predisposes to ventricular arrhythmias $[24 \cdot \bullet]$.

Until recently, it was believed that the effect of antiRo/SSA autoantibodies was confined to cardiac $\mathrm{Ca}^{2+}$ channels as described in the previous section. However, since at least the emblematic case report of a seemingly healthy woman presenting with Torsadesde-pointes (TdP) ventricular arrhythmias, we know that anti-Ro/SSA autoantibodies can cause a substantial delay in cardiac repolarization [65]. Anti-Ro/SSA autoantibodies reduce the repolarizing $I_{\mathrm{Kr}}$ current through direct inhibition of the $h$ ERG channel (human ether-à-gogo-related gene, $\mathrm{K}_{\mathrm{v}} 11.1$ or $\mathrm{KCNH} 2$ ), which results in APD lengthening and $\mathrm{QT}_{\mathrm{c}}$ prolongation $[11 \bullet \bullet, 65]$. In fact, the targeted epitope of the $h \mathrm{ERG}$ channel shares $44 \%$ sequence homology with the Ro/SSA-52kD antigen, thus advocating the binding of anti-Ro/SSA autoantibodies with the channel $[11 \bullet \cdot$. Retrospectively, several studies have previously suggested a link between anti-Ro/SSA autoantibodies and $\mathrm{QT}_{\mathrm{c}}$ prolongation in patients with autoimmune connective tissue diseases, while others found no correlation [11••, 25-32, 66-68]. Differences in autoantibody titer and subtype specificity may account for the variability in the prevalence of prolonged $\mathrm{QT}_{\mathrm{c}}$, ranging from 10 to $60 \%[11 \bullet \cdot, 25-32]$. Notably the anti-Ro/SSA-52kD subtype is held responsible for the observed proarrhythmogenic effects on the ventricles, as evidenced by Lazzerini et al. [32]. In support of the notion of autoimmune-associated long QT syndrome (LQTS), anti-Ro/SSA autoantibodies are found in $60 \%$ of patients with $\mathrm{TdP}$, mostly in the absence of any history of autoimmune disease [32].

The functional counterpart of LQTS is short QT syndrome (SQTS), characterized by an abnormally shortened ventricular repolarization secondary to a cardiac ion channel dysfunction. Traditionally, a genetic mutation is the underlying cause. In light of the emerging field of autoimmune-mediated cardiac arrhythmias, the first form of autoantibody-induced SQTS was recently identified [33]. Autoantibodies targeting the voltage-gated KCNQ1 $\mathrm{K}^{+}$channel $\left(\mathrm{K}_{\mathrm{v}} 7.1\right.$ or $\left.\mathrm{K}_{\mathrm{v}} \mathrm{LQT} 1\right)$ forming $I_{\mathrm{Ks}}$ was detected in $6 \%$ of patients with dilated cardiomyopathy and associated with a significantly shorter $\mathrm{QT}_{\mathrm{c}}$ interval [33]. The findings were reproducible in an experimental animal model immunizing rabbits with the target KCNQ1 peptide sequence [69]. In agreement with the clinical data, rabbits with KCNQ1 autoantibodies had a shorter $\mathrm{QT}_{\mathrm{c}}$ interval on ECG, shortened ventricular effective refractory period, and increased susceptibility to VT upon programmed ventricular stimulation [69]. Mechanistically, anti-KCNQ1 autoantibodies increase the open time and open probability of KCNQ1 channels $\left[70 \bullet \bullet\right.$. The resulting enhanced $I_{\mathrm{Ks}}$ current shortens the ventricular repolarization phase $[70 \bullet \cdot$.

Brugada syndrome constitutes a further primary arrhythmia syndrome next to LQTS and SQTS. It is widely accepted that a genetic mutation in a cardiac ion channel is the main cause of the condition, although structural changes and inflammatory processes have been attributed a pathogenic role [34]. Autoantibodies targeting $\alpha$-cardiac actin, $\alpha$-skeletal muscle actin, keratin-24, and connexin-43 have now been revealed as biomarkers of Brugada syndrome [34]. The functional role of these autoantibodies is not clear, and further studies will be needed to clarify the pathomechanisms underlying the autoimmune response [34].

\section{Conclusions}

The role of autoantibodies in arrhythmogenesis has long been overlooked but autoantibody-mediated arrhythmias are now 
beginning to be widely recognized as a distinct disease entity. As part of this paradigm shift, cardiac arrhythmias once classified as "idiopathic" need to be reappraised. The recognition of the autoimmune etiology is not simply a matter of terminology; it is of major importance for the management of patients. Immunosuppressive measures including immunomodulatory drugs and plasmapheresis could successfully treat patients with anti-Ro/SSA-mediated AV block [71-73]. Immunoadsorption for autoantibody removal has been effectively employed for the treatment of $\beta_{1}$-adrenergic receptor autoantibody-positive patients with dilated cardiomyopathy $[1 \bullet \bullet]$. Furthermore, peptides have been designed to neutralize the binding of pathogenic autoantibodies. Preliminary in vitro data are encouraging, but clinical studies will be needed to confirm the therapeutic potential $[1 \bullet, 11 \bullet, 22,24 \bullet \cdot]$. Finally, the discovery of an autoantibody, pathogenic for one, may actually shape up as promising new treatment approach for another. Immunotherapy for LQTS type 2 is the prototypic example $\left[69,70 \bullet \cdot\right.$. Through $I_{\mathrm{Ks}}$ upregulation, antiKCNQ1 antibodies have the potential to compensate for the loss of $I_{\mathrm{Kr}}$ as in LQTS type 2 [70••]. Accordingly, antiKCNQ1 antibodies from active immunization (KCNQ1 peptide vaccination) have been shown effective for the treatment of acquired LQTS type 2 in rabbits, while passive immunization (KCNQ1 antibody therapy) was found therapeutic in a cellular model of congenital LQTS type 2 [69, 70••]. Apart from being either a biomarker or a pathogen, natural autoantibodies exist in the healthy and are considered essential for the physiological tissue homeostasis [70••]. A recent comprehensive screening for autoantibodies targeting cardiac ion channels best illustrates the complexity of autoantibodies in healthy individuals [70••]. Their abundance and diversity imply that they may harbor some important function yet to be unveiled [70••]. Just as any puzzle solvers know, finding the corner pieces is a first step to the complete picture. While autoantibodies constitute only one such corner; inflammatory cytokines and immune cells are further pieces of the autoimmune arrhythmia puzzle [74•, 75•]. This exciting area of research in cardioimmunology is rapidly expanding, and putting together the puzzle will turn our understanding of the pathogenesis into a means for developing novel treatments of cardiac arrhythmias, becoming ever more efficient and personalized.

Funding Open access funding provided by University of Bern

\section{Compliance with Ethical Standards}

Conflict of Interest Dr. Li reports grants from the Swiss National Science Foundation (Ambizione). In addition, Dr. Li has a patent EP20167853 pending.
Human and Animal Rights and Informed Consent This article does not contain any studies with human or animal subjects performed by the author.

Open Access This article is licensed under a Creative Commons Attribution 4.0 International License, which permits use, sharing, adaptation, distribution and reproduction in any medium or format, as long as you give appropriate credit to the original author(s) and the source, provide a link to the Creative Commons licence, and indicate if changes were made. The images or other third party material in this article are included in the article's Creative Commons licence, unless indicated otherwise in a credit line to the material. If material is not included in the article's Creative Commons licence and your intended use is not permitted by statutory regulation or exceeds the permitted use, you will need to obtain permission directly from the copyright holder. To view a copy of this licence, visit http://creativecommons.org/licenses/by/4.0/.

\section{References}

Papers of particular interest, published recently, have been highlighted as:

- Of importance

•- Of major importance

1.• Becker NP, Muller J, Gottel P, Wallukat G, Schimke I. Cardiomyopathy - an approach to the autoimmune background. Autoimmun Rev. 2017;16(3):269-86. https://doi.org/10.1016/j. autrev.2017.01.012 This is an updated review on the role of autoimmunity in different cardiomyopathies and greatly presents all currently available treatment strategies for cardio-pathogenic autoantibodies.

2. Ehrlich P. On immunity with special reference to cell life. Proc R Soc Lond. 1900;66:424-48.

3. Lee HC, Huang KT, Wang XL, Shen WK. Autoantibodies and cardiac arrhythmias. Heart Rhythm. 2011;8(11):1788-95. https:// doi.org/10.1016/j.hrthm.2011.06.032.

4. Maixent JM, Paganelli F, Scaglione J, Levy S. Antibodies against myosin in sera of patients with idiopathic paroxysmal atrial fibrillation. J Cardiovasc Electrophysiol. 1998;9(6):612-7. https://doi. org/10.1111/j.1540-8167.1998.tb00942.x.

5. Baba A, Yoshikawa T, Fukuda Y, Sugiyama T, Shimada M, Akaishi M, et al. Autoantibodies against M2-muscarinic acetylcholine receptors: new upstream targets in atrial fibrillation in patients with dilated cardiomyopathy. Eur Heart J. 2004;25(13):1108-15. https://doi.org/10.1016/j.ehj.2004.05.012.

6. Yalcin MU, Gurses KM, Kocyigit D, Kesikli SA, Ates AH, Evranos B, et al. Elevated M2-muscarinic and beta1-adrenergic receptor autoantibody levels are associated with paroxysmal atrial fibrillation. Clin Res Cardiol. 2015;104(3):226-33. https://doi.org/ 10.1007/s00392-014-0776-1.

7. Mandal K, Jahangiri M, Mukhin M, Poloniecki J, Camm AJ, Xu Q. Association of anti-heat shock protein 65 antibodies with development of postoperative atrial fibrillation. Circulation. 2004;110(17): 2588-90. https://doi.org/10.1161/01.CIR.0000136825.96029.A5.

8. Oc M, Ucar HI, Pinar A, Akbulut B, Oc B, Akinci SB, et al. Heat shock protein 60 antibody. A new marker for subsequent atrial fibrillation development. Saudi Med J. 2007;28(6):844-7.

9. Kornej J, Reinhardt C, Kosiuk J, Arya A, Hindricks G, Adams V, et al. Response of circulating heat shock protein 70 and anti-heat 
shock protein 70 antibodies to catheter ablation of atrial fibrillation. J Transl Med. 2013;11:49. https://doi.org/10.1186/1479-5876-1149.

10. Chiale PA, Garro HA, Schmidberg J, Sanchez RA, Acunzo RS, Lago $\mathrm{M}$, et al. Inappropriate sinus tachycardia may be related to an immunologic disorder involving cardiac beta andrenergic receptors. Heart Rhythm. 2006;3(10):1182-6. https://doi.org/10.1016/j. hrthm.2006.06.011.

11.• Lazzerini PE, Capecchi PL, Laghi-Pasini F, Boutjdir M. Autoimmune channelopathies as a novel mechanism in cardiac arrhythmias. Nat Rev Cardiol. 2017;14(9):521-35. https://doi. org/10.1038/nrcardio.2017.61 This excellent document provides the most thorough overview on autoimmune channelopathies.

12. Hu K, Qu Y, Yue Y, Boutjdir M. Functional basis of sinus bradycardia in congenital heart block. Circ Res. 2004;94(4):e32-8. https://doi.org/10.1161/01.RES.0000121566.01778.06.

13. Brito-Zeron P, Izmirly PM, Ramos-Casals M, Buyon JP, Khamashta MA. The clinical spectrum of autoimmune congenital heart block. Nat Rev Rheumatol. 2015;11(5):301-12. https://doi. org/10.1038/nrrheum.2015.29.

14. Villuendas R, Olive A, Junca G, Salvador I, Martinez-Morillo M, Santos-Pardo I, et al. Autoimmunity and atrioventricular block of unknown etiology in adults: the role of anti-Ro/SSA antibodies. J Am Coll Cardiol. 2014;63(13):1335-6. https://doi.org/10.1016/j. jacc.2013.10.086.

15. Chiale PA, Ferrari I, Mahler E, Vallazza MA, Elizari MV, Rosenbaum MB, et al. Differential profile and biochemical effects of antiautonomic membrane receptor antibodies in ventricular arrhythmias and sinus node dysfunction. Circulation. 2001;103(13): 1765-71. https://doi.org/10.1161/01.cir.103.13.1765.

16. Nussinovitch $U$, Shoenfeld $Y$. The diagnostic and clinical significance of anti-muscarinic receptor autoantibodies. Clin Rev Allergy Immunol. 2012;42(3):298-308. https://doi.org/10.1007/s12016$010-8235-\mathrm{x}$

17. Hernandez CC, Nascimento JH, Chaves EA, Costa PC, Masuda MO, Kurtenbach E, et al. Autoantibodies enhance agonist action and binding to cardiac muscarinic receptors in chronic Chagas' disease. J Recept Signal Transduct Res. 2008;28(4):375-401. https://doi.org/10.1080/10799890802262319.

18. Korkmaz S, Zitron E, Bangert A, Seyler C, Li S, Hegedus P, et al. Provocation of an autoimmune response to cardiac voltage-gated sodium channel $\mathrm{NaV} 1.5$ induces cardiac conduction defects in rats. J Am Coll Cardiol. 2013;62(4):340-9. https://doi.org/10.1016/j. jacc.2013.04.041.

19. Chiale PA, Rosenbaum MB, Elizari MV, Hjalmarson A, Magnusson Y, Wallukat G, et al. High prevalence of antibodies against beta 1 - and beta 2-adrenoceptors in patients with primary electrical cardiac abnormalities. J Am Coll Cardiol. 1995;26(4): 864-9. https://doi.org/10.1016/0735-1097(95)00262-2.

20. Brisinda D, Sorbo AR, Venuti A, Ruggieri MP, Manna R, Fenici P, et al. Anti-beta-adrenoceptors autoimmunity causing 'idiopathic' arrhythmias and cardiomyopathy. Circ J. 2012;76(6):1345-53. https://oi.org/10.1253/circj.cj-11-1374.

21. Baba A, Yoshikawa T, Ogawa S. Autoantibodies produced against sarcolemmal Na-K-ATPase: possible upstream targets of arrhythmias and sudden death in patients with dilated cardiomyopathy. $\mathrm{J}$ Am Coll Cardiol. 2002;40(6):1153-9. https://doi.org/10.1016/ s0735-1097(02)02075-2.

22. Xiao H, Wang M, Du Y, Yuan J, Cheng X, Chen Z, et al. Arrhythmogenic autoantibodies against calcium channel lead to sudden death in idiopathic dilated cardiomyopathy. Eur J Heart Fail. 2011;13(3):264-70. https://doi.org/10.1093/eurjhf/hfq198.

23. Xiao H, Wang M, Du Y, Yuan J, Zhao G, Tu D, et al. Agonist-like autoantibodies against calcium channel in patients with dilated cardiomyopathy. Heart Vessel. 2012;27(5):486-92. https://doi. org/10.1007/s00380-011-0176-7.

24.• Maguy A, Tardif JC, Busseuil D, Ribi C, Li J. Autoantibody signature in cardiac arrest. Circulation. 2020;141(22):1764-74. https://doi.org/10.1161/CIRCULATIONAHA.119.044408 This is the first comprehensive screening of autoantibodies directed against all known cardiac ion channels, establishing autoantibody profiles of patients with cardiac arrest and healthy individuals.

25. Lazzerini PE, Acampa M, Guideri F, Capecchi PL, Campanella V, Morozzi G, et al. Prolongation of the corrected QT interval in adult patients with anti-Ro/SSA-positive connective tissue diseases. Arthritis Rheum. 2004;50(4):1248-52. https://doi.org/10.1002/art. 20130

26. Lazzerini PE, Capecchi PL, Guideri F, Bellisai F, Selvi E, Acampa $\mathrm{M}$, et al. Comparison of frequency of complex ventricular arrhythmias in patients with positive versus negative anti-Ro/SSA and connective tissue disease. Am J Cardiol. 2007;100(6):1029-34. https://doi.org/10.1016/j.amjcard.2007.04.048.

27. Bourre-Tessier J, Clarke AE, Huynh T, Bernatsky S, Joseph L, Belisle $\mathrm{P}$, et al. Prolonged corrected QT interval in anti-Ro/SSApositive adults with systemic lupus erythematosus. Arthritis Care Res. 2011;63(7):1031-7. https://doi.org/10.1002/acr.20470.

28. Lazzerini PE, Capecchi PL, Acampa M, Morozzi G, Bellisai F, Bacarelli MR, et al. Anti-Ro/SSA-associated corrected QT interval prolongation in adults: the role of antibody level and specificity. Arthritis Care Res. 2011;63(10):1463-70. https://doi.org/10.1002/ acr.20540.

29. Pisoni CN, Reina S, Arakaki D, Eimon A, Carrizo C, Borda E. Elevated IL-1beta levels in anti-Ro/SSA connective tissue diseases patients with prolonged corrected QTc interval. Clin Exp Rheumatol. 2015;33(5):715-20.

30. Sham S, Madheshwaran M, Tamilselvam TN, Rajeswari S. Correlation of QT interval with disease activity in newly detected SLE patients at baseline and during flare. Indian $\mathrm{J}$ Rheumatol. 2015;10:121-4

31. Tufan AN, Sag S, Oksuz MF, Ermurat S, Coskun BN, Gullulu M, et al. Prolonged Tpeak-tend interval in anti-Ro52 antibody-positive connective tissue diseases. Rheumatol Int. 2017;37(1):67-73. https://doi.org/10.1007/s00296-016-3488-1.

32. Lazzerini PE, Yue Y, Srivastava U, Fabris F, Capecchi PL, Bertolozzi I, et al. Arrhythmogenicity of anti-Ro/SSA antibodies in patients with torsades de pointes. Circ Arrhythm Electrophysiol. 2016;9(4):e003419. https://doi.org/10.1161/CIRCEP.115.003419.

33. Li J, Seyler C, Wiedmann F, Schmidt C, Schweizer PA, Becker R, et al. Anti-KCNQ1 K(+) channel autoantibodies increase IKs current and are associated with QT interval shortening in dilated cardiomyopathy. Cardiovasc Res. 2013;98(3):496-503. https://doi. org $/ 10.1093 / \mathrm{cvr} / \mathrm{cvt} 046$.

34. Chatterjee D, Pieroni M, Fatah M, Charpentier F, Cunningham KS, Spears DA, et al. An autoantibody profile detects Brugada syndrome and identifies abnormally expressed myocardial proteins. Eur Heart J. 2020;41:2878-90. https://doi.org/10.1093/eurheartj/ ehaa383.

35. He B, Lu Z, He W, Jiang H. Autoantibodies against M2-muscarinic and beta adrenergic receptors: new mediators in atrial fibrillation? Int J Cardiol. 2015;197:180-1. https://doi.org/10.1016/j.ijcard. 2015.06.066.

36. Hu B, Sun Y, Li S, Sun J, Liu T, Wu Z, et al. Association of beta1adrenergic, M2-muscarinic receptor autoantibody with occurrence and development of nonvalvular atrial fibrillation. Pacing Clin Electrophysiol. 2016;39(12):1379-87. https://doi.org/10.1111/ pace.12976.

37. Yalcin MU, Gurses KM, Kocyigit D, Kesikli SA, Dural M, Evranos $\mathrm{B}$, et al. Cardiac autoantibody levels predict recurrence following cryoballoon-based pulmonary vein isolation in paroxysmal atrial 
fibrillation patients. J Cardiovasc Electrophysiol. 2015;26(6):61521. https://doi.org/10.1111/jce.12665.

38. Zou C, Zhang Z, Zhao W, Li G, Ma G, Yang X, et al. Predictive value of pre-procedural autoantibodies against M2-muscarinic acetylcholine receptor for recurrence of atrial fibrillation one year after radiofrequency catheter ablation. J Transl Med. 2013;11:7. https:// doi.org/10.1186/1479-5876-11-7.

39. Li H, Scherlag BJ, Kem DC, Zillner C, Male S, Thirunavukkarasu $\mathrm{S}$, et al. Atrial tachycardia provoked in the presence of activating autoantibodies to beta2-adrenergic receptor in the rabbit. Heart Rhythm. 2013;10(3):436-41. https://doi.org/10.1016/j.hrthm. 2012.11.010.

40. Li H, Scherlag BJ, Kem DC, Benbrook A, Shen X, Cunningham MW, et al. Inducible cardiac arrhythmias caused by enhanced beta1-adrenergic autoantibody expression in the rabbit. Am $\mathrm{J}$ Physiol Heart Circ Physiol. 2014;306(3):H422-8. https://doi.org/ 10.1152/ajpheart.00551.2013.

41. Hong CM, Zheng QS, Liu XT, Shang FJ, Wang HT, Jiang WR. Effects of autoantibodies against M2 muscarinic acetylcholine receptors on rabbit atria in vivo. Cardiology. 2009;112(3):180-7. https://doi.org/10.1159/000149152.

42. Gurses KM, Yalcin MU, Kocyigit D, Kesikli SA, Canpolat U, Yorgun $\mathrm{H}$, et al. M2-muscarinic acetylcholine receptor autoantibody levels predict left atrial fibrosis severity in paroxysmal lone atrial fibrillation patients undergoing cryoablation. Europace. 2015;17(2):239-46. https://doi.org/10.1093/europace/euu228.

43. Baba A, Fu M. Autoantibodies in atrial fibrillation: actor, biomaker or bystander? Autoimmunity. 2008;41(6):470-2. https://doi.org/10. 1080/08916930802031504.

44. Olshansky B, Sullivan RM. Inappropriate sinus tachycardia. J Am Coll Cardiol. 2013;61(8):793-801. https://doi.org/10.1016/j.jacc. 2012.07.074

45. Fairfax A, Doniach D. Autoantibodies to cardiac conducting tissue and their characterization by immunofluorescence. Clin Exp Immunol. 1976;23(1):1-8.

46. Ambrosi A, Dzikaite V, Park J, Strandberg L, Kuchroo VK, Herlenius E, et al. Anti-Ro52 monoclonal antibodies specific for amino acid 200-239, but not other Ro52 epitopes, induce congenital heart block in a rat model. Ann Rheum Dis. 2012;71(3):44854. https://doi.org/10.1136/annrheumdis-2011-200414.

47. Ruffatti A, Marson P, Svaluto-Moreolo G, Marozio L, Tibaldi M, Favaro M, et al. A combination therapy protocol of plasmapheresis, intravenous immunoglobulins and betamethasone to treat anti-Ro/ La-related congenital atrioventricular block. A case series and review of the literature. Autoimmun Rev. 2013;12(7):768-73. https:// doi.org/10.1016/j.autrev.2013.01.002.

48. Saxena A, Izmirly PM, Mendez B, Buyon JP, Friedman DM. Prevention and treatment in utero of autoimmune-associated congenital heart block. Cardiol Rev. 2014;22(6):263-7. https://doi.org/ 10.1097/CRD.0000000000000026.

49. Cuneo BF, Sonesson SE, Levasseur S, Moon-Grady AJ, Krishnan A, Donofrio MT, et al. Home monitoring for fetal heart rhythm during anti-Ro pregnancies. J Am Coll Cardiol. 2018;72(16): 1940-51. https://doi.org/10.1016/j.jacc.2018.07.076.

50. Evers PD, Alsaied T, Anderson JB, Cnota JF, Divanovic AA. Prenatal heart block screening in mothers with SSA/SSB autoantibodies: targeted screening protocol is a cost-effective strategy. Congenit Heart Dis. 2019;14(2):221-9. https://doi.org/10.1111/ chd. 12713 .

51. Salomonsson S, Strandberg L. Autoantibodies associated with congenital heart block. Scand J Immunol. 2010;72(3):185-8. https:// doi.org/10.1111/j.1365-3083.2010.02442.x.

52. Orth T, Dorner T, Meyer Zum Buschenfelde KH, Mayet WJ. Complete congenital heart block is associated with increased autoantibody titers against calreticulin. Eur J Clin Investig. 1996;26(3): 205-15. https://doi.org/10.1046/j.1365-2362.1996.120270.x.
53. Borda E, Sterin-Borda L. Autoantibodies against neonatal heart M1 muscarinic acetylcholine receptor in children with congenital heart block. J Autoimmun. 2001;16(2):143-50. https://doi.org/10.1006/ jaut.2000.0461.

54. Miyagawa S, Yanagi K, Yoshioka A, Kidoguchi K, Shirai T, Hayashi Y. Neonatal lupus erythematosus: maternal $\mathrm{IgG}$ antibodies bind to a recombinant $\mathrm{NH} 2$-terminal fusion protein encoded by human alpha-fodrin cDNA. J Invest Dermatol. 1998;111(6): 1189-92. https://doi.org/10.1046/j.1523-1747.1998.00440.x.

55. Locht H, Pelck R, Manthorpe R. Diagnostic and prognostic significance of measuring antibodies to alpha-fodrin compared to antiRo-52, anti-Ro-60, and anti-La in primary Sjogren's syndrome. J Rheumatol. 2008;35(5):845-9.

56. Llanos C, Chan EK, Li S, Abadal GX, Izmirly P, Byrne C, et al. Antibody reactivity to alpha-enolase in mothers of children with congenital heart block. J Rheumatol. 2009;36(3):565-9. https:// doi.org/10.3899/jrheum.080860.

57. Kamel R, Eftekhari P, Clancy R, Buyon JP, Hoebeke J. Autoantibodies against the serotoninergic 5-HT4 receptor and congenital heart block: a reassessment. J Autoimmun. 2005;25(1):726. https://doi.org/10.1016/j.jaut.2005.04.005.

58. Maisch B, Ristic AD. Immunological basis of the cardiac conduction and rhythm disorders. Eur Heart J. 2001;22(10):813-24. https://doi.org/10.1053/euhj.2000.2186.

59. Lazzerini PE, Capecchi PL, Acampa M, Selvi E, Guideri F, Bisogno S, et al. Arrhythmogenic effects of anti-Ro/SSA antibodies on the adult heart: more than expected? Autoimmun Rev. 2009;9(1):40-4. https://doi.org/10.1016/j.autrev.2009.03.002.

60. Nussinovitch U, Shoenfeld Y. The clinical significance of anti-beta1 adrenergic receptor autoantibodies in cardiac disease. Clin Rev Allergy Immunol. 2013;44(1):75-83. https://doi.org/10.1007/ s12016-010-8228-9.

61.• Ryabkova VA, Shubik YV, Erman MV, Churilov LP, Kanduc D, Shoenfeld Y. Lethal immunoglobulins: autoantibodies and sudden cardiac death. Autoimmun Rev. 2019;18(4):415-25. https://doi. org/10.1016/j.autrev.2018.12.005 This is the most recent and comprehensive review on autoantibodies in a variety of cardiac diseases.

62. Zuo L, Du Y, Ma J, Wang K, Zhao Y, Bai F, et al. Pro-arrhythmic action of autoantibodies against the second extracellular loop of beta1-adrenoceptor and its underlying molecular mechanisms. Int J Cardiol. 2015;198:251-8. https://doi.org/10.1016/j.ijcard.2015. 06.144.

63. Zhao Y, Huang H, Du Y, Li X, Lv T, Zhang S, et al. beta1Adrenoceptor autoantibodies affect action potential duration and delayed rectifier potassium currents in guinea pigs. Cardiovasc Toxicol. 2015;15(1):1-9. https://doi.org/10.1007/s12012-0149261-3.

64. Bers DM, Despa S. Na/K-ATPase-an integral player in the adrenergic fight-or-flight response. Trends Cardiovasc Med. 2009;19(4): 111-8. https://doi.org/10.1016/j.tcm.2009.07.001.

65. Yue Y, Castrichini M, Srivastava U, Fabris F, Shah K, Li Z, et al. Pathogenesis of the novel autoimmune-associated long-QT syndrome. Circulation. 2015;132(4):230-40. https://doi.org/10.1161/ CIRCULATIONAHA.115.009800.

66. Costedoat-Chalumeau N, Amoura Z, Hulot JS, Ghillani P, Lechat $\mathrm{P}$, Funck-Brentano $\mathrm{C}$, et al. Corrected QT interval in anti-SSApositive adults with connective tissue disease: comment on the article by Lazzerini et al. Arthritis Rheum. 2005;52(2):676-7; author reply 7-8. https://doi.org/10.1002/art.20845.

67. Massie C, Hudson M, Tatibouet S, Steele R, Huynh T, Fritzler MJ, et al. Absence of an association between anti-Ro antibodies and prolonged QTc interval in systemic sclerosis: a multicenter study of 689 patients. Semin Arthritis Rheum. 2014;44(3):338-44. https://doi.org/10.1016/j.semarthrit.2014.07.001. 
68. Bourre-Tessier J, Urowitz MB, Clarke AE, Bernatsky S, Krantz MJ, Huynh T, et al. Electrocardiographic findings in systemic lupus erythematosus: data from an international inception cohort. Arthritis Care Res. 2015;67(1):128-35. https://doi.org/10.1002/ acr.22370.

69. Li J, Maguy A, Duverger JE, Vigneault P, Comtois P, Shi Y, et al. Induced KCNQ1 autoimmunity accelerates cardiac repolarization in rabbits: potential significance in arrhythmogenesis and antiarrhythmic therapy. Heart Rhythm. 2014;11(11):2092-100. https:// doi.org/10.1016/j.hrthm.2014.07.040.

70.• Maguy A, Kucera JP, Wepfer JP, Forest V, Charpentier F, Li J. KCNQ1 antibodies for Immunotherapy of long QT syndrome type 2. J Am Coll Cardiol. 2020;75(17):2140-52. https://doi.org/10. 1016/j.jacc.2020.02.067 This is the first proof-of-concept of immunotherapy as a potential treatment for long QT syndrome type 2.

71. Santos-Pardo I, Martinez-Morillo M, Villuendas R, Bayes-Genis A. Anti-Ro antibodies and reversible atrioventricular block. N Engl J Med. 2013;368(24):2335-7. https://doi.org/10.1056/ NEJMc1300484.

72. Saribayev M, Tufan F, Oz F, Erer B, Ozpolat T, Ozturk GB, et al. Corticosteroid treatment normalizes QTc prolongation and improves heart block in an elderly patient with anti-Ro-positive systemic lupus erythematosus. Aging Clin Exp Res. 2014;26(3): 337-9. https://doi.org/10.1007/s40520-013-0168-9.

73. Lazzerini PE, Brucato A, Capecchi PL, Baldi L, Bacarelli MR, Nucci C, et al. Isolated atrioventricular block of unknown origin in the adult and autoimmunity: diagnostic and therapeutic considerations exemplified by 3 anti-Ro/SSA-associated cases. HeartRhythm Case Rep. 2015;1(5):293-9. https://doi.org/10. 1016/j.hrcr.2015.03.019.

74. Lazzerini PE, Capecchi PL, El-Sherif N, Laghi-Pasini F, Boutjdir M. Emerging arrhythmic risk of autoimmune and inflammatory cardiac channelopathies. J Am Heart Assoc. 2018;7(22):e010595. https://doi.org/10.1161/JAHA.118.010595 This is a comprehensive review on autoimmune and inflammatory channelopathies.

75. Swirski FK, Nahrendorf M. Cardioimmunology: the immune system in cardiac homeostasis and disease. Nat Rev Immunol. 2018;18(12):733-44. https://doi.org/10.1038/s41577-018-0065-8 This remarkable document focuses on the role of the cellular immune system in a variety of cardiac conditions.

Publisher's Note Springer Nature remains neutral with regard to jurisdictional claims in published maps and institutional affiliations. 